\title{
Neutrophils and Leukocytes on Shallot Spraying Farmers
}

\author{
Rohmatul Mukharomah \\ ${ }^{1}$ Poltekkes Kemenkes Semarang, Semarang, 50192, Indonesia \\ 1'rohmatulm@yahoo.com \\ * corresponding author \\ Submission date: 2022-01-20, Receipt date: 2022-01-20, Publication date: 2022-01-21
}

\begin{abstract}
Brebes is one of thr producer onionhighest in indonesia. Many farmers spraying the wrong onion in the use of pesticides. Pesticide will can be toxic if entry the body. So can distrub blood profilespray farmers onion, increaseLeukocyte and neutrophil in case of infection. Knowing desription leukocyte and neutrophil on onion spray farmers at village Karanganyar Larangan Brebes. Method of this research uses descriptive research with cross sectional type of study.sampel is 31 onion spray farmers at village Karanganyar Larangan Brebes. Research result for leukocyte 28 spray onion farmer have according to the reference value and 3 spray onion farmer have exceeds the reference value. Neutrophil on onnion spray farmers 16 has according to the reference value, 12 farmer under to the reference, 2 farmer exceeds the reference, and 1 farmer has a critical value.Means of neutrophil is $51 \%$ in spray farmers onion at vilage Karanganyar Larangan Brebes, means of leukocyte $8300 \mu l$. Precentage of neutrophil $90,32 \%$ according of the reference, 9,68\% exceed to the reference, $38,68 \%$ under to the reference.
\end{abstract}

Keywords: Neutrophils; Leukocyte; Pesticide

\section{INTRODUCTION}

Central Java Province is one of the shallot producers in Indonesia which contributes about $23.14 \%$ of the national shallot production. Shallot production in Central Java in 2011 amounted to 372,256 tons and in 2012 amounted to 381,813 tons with a growth rate of $27.57 \%$. The area that is well-known for producing shallots in Central Java is Brebes Regency which produces shallots with a supply of 326,424 tons which contributes about $38.2 \%$ of the national production or $79.1 \%$ in Central Java.

Shallots for Brebes Regency is a trade mark considering its position as the largest producer of this commodity not only at the Central Java Province level but also at the national level. The shallot-producing sub-districts in Brebes Regency include Larangan, Wanasari, Brebes, Bulakamba, and Jatibarang Districts.

Data from the Central Bureau of Statistics of Brebes Regency in 2014, Larangan District is the largest producer in Brebes Regency with a productivity of $1,004,856$ 
quintals. One of the hamlets in Larangan sub-district, Karanganyar hamlet, consists of 309 families and 146 household heads who work as shallot-spray farmers. The use of pesticides on shallot plants that violate the regulations is very vulnerable due to the increasing market demands for shallot production. Pesticide is a chemical substance that is used to kill or prevent various pests so that shallot plants can be protected from pests and the productivity of shallots can be increased. Pesticides are actually poisons when they enter the body and can affect the blood profile.

The results of observations that have been made to farmers spraying shallots in the Karanganyar Larangan hamlet of Brebes, farmers mix several types of pesticides and at a dose that exceeds the dose that has been set on the pesticide packaging bottle. When mixing and spraying farmers do not use personal protective equipment such as masks, gloves, hats, long sleeves, and boots. On average, farmers spray 3 times a week with a duration of 2-3 hours. Farmers spraying shallots in the Karangayar Larangan hamlet of Brebes stated that they felt dizzy, itchy, red eyes, and nauseated. These symptoms can occur exposure to pesticides that affect the blood profile.

Blood profile is an important component in assessing a person's health. There are various factors that can affect a person's blood profile including age, gender, health status, and environment. Pesticides are thought to be one of the environmental factors that also affect the blood profile. Several studies have shown the effect of pesticide exposure on blood profile. The body's defenses will have an effect if there are foreign substances or toxins that enter the body such as pesticides.

White blood cells or leukocytes are a mobile unit of the body's defense system. The total number of leukocytes under normal circumstances ranges from 3200-10,000 cells $/ \mathrm{mm} 3$ of blood with an average of 7,000 cells $/ \mathrm{mm} 3$. There are five types of leukocytes that can be found in the blood. The five cells are neutrophils, eosinophils, basophils, monocytes and lymphocytes. Neutrophils function to protect the body against invading organisms such as bacteria, viruses or other foreign particles by ingesting these substances. So that there can be an influence on the number of leukocytes and neutrophils if toxic pesticides enter the body.

Based on the above background, the researchers wanted to know the description of neutrophils and leukocytes in shallot spraying farmers in Karanganyar Larangan, Brebes Hamlet.

The purpose of this study was to determine the description of neutrophils and leukocytes in onion spraying farmers in Karanganyar Larangan Hamlet, Brebes.

\section{RESEARCH METHODS}

The research method used is descriptive research with a cross-sectional research design. The sample size is 31 shallot spray farmers in Karanganyar Larangan, Brebes Hamlet. Examination using a Hematology Analyzer (pocH-100i).

\section{RESULTS AND DISCUSSION}

The study on shallot spraying farmers in Karanganyar Hamlet, Larangan District, Brebes Regency was conducted in April 2018. The respondents in this study were all male as many as 31 farmers. All of these subjects were spraying pesticides on shallots in Karanganyar Larangan Hamlet, Brebes Regency. 
Examination of neutrophils on shallot-spray farmers in Karanganyar Larangan, Brebes Hamlet, from 31 samples of 12 people, had a neutrophil count below normal with a percentage of $38.70 \%$. This is in line with the research conducted by Azmi (2009) which compared the blood parameters of farmers exposed to pesticides and the blood of normal people in Pakistan, the results showed that the average neutrophil count of farmers was lower than normal people. This is presumably because the use of inappropriate doses can be seen in Appendix 1 table 10, there are 36\% of farmers spraying shallots not in accordance with the dose when spraying shallots, then in the use of personal protective equipment many shallot spraying farmers do not use tools. Personal protective equipment correctly or included in the bad category can be seen in appendix 1 table 14 there are $39 \%$ of shallot spraying farmers incorrectly in using personal protective equipment which easily enters the sprayer farmer's body causing toxicity in the body according to Repetto's research (2007) showed that pesticides can impair neutrophil function. The farmers had indications of suppression of neutrophil function, such as upper respiratory tract infections, which correlated with the duration of pesticide exposure. Although upper respiratory tract infections are associated with pesticide exposure.

Examination of neutrophils on onion spraying farmers in Karanganyar Larangan, Brebes Hamlet, from 31 samples of 2 people, had a neutrophil count above normal with a percentage of $6.46 \%$. The neutrophil count was still in the safe limit or did not exceed the high limit value for the neutrophil count. This could be due to infection or inflammation in the respondent's body. Research subjects have a smoking habit. According to Galang (2016), exposure to smoking smoke can trigger inflammation in the body so that it can increase the number of neutrophils in the body.

Examination of neutrophils on shallot spraying farmers in Karanganyar Larangan Brebes Hamlet from 31 samples of 1 person had a neutrophil count below normal with a percentage of $3.23 \%$ having a neutrophil count below the reference value or it can be said that neutropenia (lack of neutrophil count in the blood). According to Vanda's previous research (2016), it is said to be neutropenic if the number of neutrophils is less than 37\%. According to the Ministry of Health (2011), neutropenia, a lack of neutrophils, can be caused by a lack of neutrophil production, cell damage, chemical infections, hematological diseases, hormonal disorders and severe infections. Many factors can cause neutropenia. It is suspected that the research subjects did not pay attention to the direction of spraying, which can be seen in table 10. Repetto (2007) shows that pesticides can damage the function of neutrophils. These farmers have indications of suppression of neutrophil function, such as upper respiratory tract infection which correlates with the duration of pesticide exposure but the pathological mechanism is not known for certain.

Examination of leukocytes on shallot spraying farmers in Karanganyar Larangan Brebes Hamlet from 31 samples of 3 people had a leukocyte count above normal with a percentage of $9.68 \%$, based on filling out the questionnaire and interview results had a history of strep throat. This is thought to cause the leukocyte count to be above the reference value. Leukocytes perform phagocytosis and kill microorganisms or foreign objects. The activity of the natural immune system produces an inflationary response which is essential for rapid control of infection. (Ari ,2012) 


\section{CONCLUSION}

The average number of neutrophils in shallot spraying farmers in Karanganyar Larangan, Brebes Hamlet is 51\%. The average number of leukocytes in shallot spraying farmers in Karanganyar Larangan, Brebes Hamlet is 8,300 $\mu 1$. The number of leukocytes in onion spraying farmers in Karanganyar Larangan Brebes Hamlet has a value above normal, this is presumably when spraying the research subjects did not pay attention to wind direction, used doses that were not in accordance with the packaging, had a history of strep throat. The number of neutrophils has a number above normal, below normal and a critical value, it is suspected that the research subject has a history of smoking habits, does not pay attention to wind direction, does not pay attention to the use of pesticide doses. Farmers spraying shallots in Karanganyar Hamlet Brebes prohibition is advised to bring personal protective equipment when spraying in order to reduce the risk of pesticide poisoning

\section{REFERENCES}

Azmi M, Naqvi S, Akhtar K, Moinuddin, Parveen S, Parveen R, et al. (2009). Effect of pesticide residues on health and blood parameters of farm workers from rural Gudap, Karachi, Pakistan. Journal of Environmental Biology. 748-56.

Ganong. William F, (2008). Buku Ajar Fisiologi Kedokteran (Review of Medical Physiology, 22/e), Penerbit : Buku Kedokteran EGC, Jakarta

Hasibuan, Malayu S.P. (2016). Manajemen Sumber Daya Manusia. Edisi Revisi. Jakarta: Penerbit PT Bumi Aksara

Mahmudah muamilatul, Dkk. (2012). Kejadian Keracunan Pestisida Pada Istri Petani Bawang Merah di Desa Kenguter Kecamatan Brebes Kabupaten Brebes:Kesehatan Lingkungan FKM Universitas Diponegoro

Olivia, Vanda. (2016). Gambaran Darah Tepi Pada Penderita Karsinoma Nasofaring Sebelum dan Sesudah Kemoradiotrafi di RSUP. H. Adam Malik 2015: Fakultas Kedokteran Universitas Sumatera Medan

Petro-Nustas, W., Tsangari, H., Phellas, C., \& Constantinou, C. (2013). Health beliefs and practice of breast self-examination among young Cypriot women. Journal of Transcultural Nursing, 24(2), 180-188.

https://doi.org/10.1177/1043659612472201

Polir Hedison, Dkk. (2013). Jumlah Neutrofil Pada Petani Terpapar Pestisida di Kelurahan Rurukan Kecamatan Tomoho Timur: Fakultas Kedokteran Universitas Sam Ratulangi Manado.

Repetto R, Baliga S. (1996) Pesticide and The Immune System: The Public Health Risk. World Resources Institute; h. 44-5.

Runia, Y.A. (2008). Faktor-faktor yang berhubungan dengan keracunan pestisida organofosfat,karbamat dan kejadian anemia pada petani hortikultura di Desa Tejosari kecamatan Ngablak Kabupaten Magelang: Fakultas Kesehatan Lingkungan. 